\title{
THE EFFECT OF 3-2-1 STRATEGY ON IRAQI EFL PREPARATORY SCHOOL STUDENTS' SPEAKING PERFORMANCE AND SELF- EFFICACY
}

\author{
Beidaa Jasim, Prof. Dr. Salam Hamid Abbas \\ University of Baghdad \\ College of Education/Ibn Rushd for Human Sciences
}

DOI: $10.37648 / \mathrm{ijrssh} . v 10 \mathrm{i} 02.013$

Received:12 $2^{\text {th }}$ January, 2020; Accepted:06 $6^{\text {th }}$ February, 2020; Published: $26^{\text {th }}$ February, 2020

\section{ABSTRACT}

Speaking is the most crucial skill among the four skills since it is the one that every student needs to communicate with other students in the classroom and the teacher for the purpose of sharing ideas, feelings, and thoughts. On the other hand, students' capability to learn to speak is mainly related to their beliefs in their abilities and their own inner potentials since it determines whether they feel being efficacious or not.

The current study aims at finding out the effect of 3-2-1 strategy on Iraqi EFL preparatory school students' speaking performance and self-efficacy. Sixty four preparatory school students have randomly been chosen (thirty two students in each of the experiential group and control group) during the academic year 2018-2019. To achieve the aims of the study, two instruments are utilized; a speaking test and a speaking self-efficacy scale. The statistical analysis of the data obtained by the two instruments indicate that there are significant differences between the experimental group speaking performance and that of the control group in favor of the experimental group.

This study has inferred that utilizing 3-2-1 strategy can improve students' speaking performance and maintains and reboots students' beliefs in their self-efficacy to learn and speak the target language.

Keywords: speaking performance, speaking self-efficacy, 3-2-1 strategy

\section{INTRODUCTION}

Speaking represents a means of dominance in communication. Through speaking people can explain what they exactly feel, think, or face at every state they go through. Speaking can be described as a synergistic procedure to establish meaning which encompasses generating and receiving and operating information. The form and meaningofspeaking are impacted by the setting in which it occurs, the participants, and the purpose of speaking. (Burns\&Joyce, 1997)

Nunan (1991:39) states that doing well in a speaking situation in the target language represents the most important indicator of effective language learning. In spite of possessing the motive andinterest to learn a foreign language, language learners encounter so many hurdles in their journey to become speakers of that language which ends really bad for most of them. 
On the other hand, research results from several areas indicate that self-efficacy is a key factor that affects learners' interest, persistence, extent of effort students invest in learning, the goals they choose to pursue and their use of self-regulated strategies in carrying out a task (Pajares, 1996:12; Schunk, 1981:5). Accordingly, promoting students' self-efficacy in their speaking may motivate them to act more resilient and focus on each activity and task which can lead them not only to think in English but most importantly to speak in English.

Iraq is one of the countries in which English language is taught as a foreign language and as one of the main subjects in all educational levels. The teaching of English language starts from kindergarten up to the higher grades in the university levels. Despite the long years of learning the target language inside the classrooms, Iraqi EFL learners mostly do not have the capacity to use it to communicatefluently.(AlShimmary,2003:1) and (Al-Salihi,2006:3).

In this study, a new teaching strategy (3-2-1 strategy) is experimented to find out whether, or not, it is effective in improving students' speaking performance and self-efficacy.

\section{AIMS}

The study aims at:

1. Finding out the effect of 3-2-1 strategy on Iraqi EFL preparatory school students' speaking performance.

2. Finding out the effect of 3-2-1 strategy on Iraqi EFL preparatory school students' speaking self-efficacy.

\section{LIMITS}

The study is limited to:

- Iraqi preparatory school students

- $\quad$ Speaking activities in the prescribed textbook 'English for Iraq' for $5^{\text {th }}$ stage.

- $\quad$ The academic year 2018-2019.

\section{HYPOTHESES}

To achieve the aim of the study, the following null hypotheses have been tested:

1-there is no statistical significant difference between the mean score of the experimental group students who are taught speaking by 3-2-1strategy and that of the control group students who are taught speaking conventionally in the speaking performance post-test.

2-there is no statistical significant difference between the mean score of the experimental group students who are taught speaking by 3-2-1strategy and that of the control group students who are taught speaking conventionally in the self-efficacy scale.

\section{REVIEW OF LITERATURE}

\section{The significance of speaking}

Speaking is an everyday necessity that human beings demands to communicate with each other and to transform their feelings and ideas into uttered words. Speaking is "an interactive process of constructing meaning that involves producing and receiving and processing information" (Florez, 1999: 1).

Speaking is acknowledged by everybody as fundamental language-communication skillfulness; however its significance to language learners goes beyond only everyday communication. It can expedite acquiring the target language and contribute towards the academic improvement of considerable number of foreign language learners. (Burns \&ChuenMeng, 2012:15)

Being the most crucial means in our communication system, speaking performance functions as the most important part in our daily lives. Any aspect of life whether it's our societal or personal communication needs our capability to talk since it's really the only way out to keep our interaction process working. Cushman \& Cahn (1985:13) argues that speaking is a diverse communication framework whose main goal is to organize agreement regarding the realization this cross -cultural diversity and the coordination of a nation's political, economic, and social capacities with different nations. 
Celce-Murcia (2001-103) claims that "the ability to speak a language is synonymous with knowing that language since speech is the most basic means of human communication". This also has been noted by Ur (2000:12) among the four language learning skills, speaking appears to be naturally the most significant. This significance comes from the fact that learners who have the ability to speak a target language are referred to as speakers of the language, which gives the impression that speaking incorporates every single other sort of knowledge.

"Baker \&Westrup (2003:5) believe that many educators believe that language learners who succeed in both learning a foreign language and utilizing it not only inside the classroom but outside and in everyday life situations may have a considerable chance for higher education, more prominent shot for further training, a better chance to be employed in the future, and even acquiring promotions.

The ingenuity of speaking a foreign and universal language like English represents an advantage for many second or foreign language learners .Thus, it seems that learners predominantly estimate their accomplishment in language learning as well as the leverage of their foreign language learning whether at schools or in language training courses on the base of how much they believe they have improved in their uttered language dexterity (Richards 2008:19).

\section{THE RATIONALISTIC REASONS BEHIND LEARNING TO SPEAK}

Many educators believe that learning to speak can mostly be done for two reasons:

\section{1-Speaking for learning}

Speaking a foreign language represents the most sophisticated skill to be acquired by learners since being a demandingskill from both learners and teachers, but it calls for much from the

learners side. MacCarthy (1972:9) sees that "when people are learning to speak a language, they are concerned mainly with two things:(1)knowing what to say -what words and phrases to use at any given moment, in any giving situation and (2)being able to say it -able to perform the required actions, the movement necessary, for saying those words and phrases aloud". This means learners are in need for a lot of skills to be able to use the foreign language as native speakers.

\section{2-Speaking to communicate}

Using language is the humans' only natural way to interact and this kind of interaction can only be done through utilizing the language in speaking. For the purpose of expressing ideas, feelings and to communicate effectively with other members in the society humans need to speak. In order to interact with each other, people have to speak and speaking doesn't only mean knowing the language system, and this knowledge encompasses figuring out a number of features such as bridging any information gap and knows what to say and how to say it. speaking is seen as a fundamental verbal connection among individuals in the community. Speaking skill can only avail as the only naturalistic way of communication among individuals of the society for both the notification of ideas and the structure of a social attitude (Caroline ,2005:45).

To communicate learners need to be able to speak in the first place. Widdowson (1990:27) notes that It is obvious that picking up only the language system isn't the fitting path for figuring out how to interact in the FL since knowing only the language rules alone does not give language learners the comprehensive clarification of the real requirements of communicating and reacting with others in the foreign language.

\section{THE NOTION OF SELF-EFFICACY}

Self-efficacy can be defined as peoples inner beliefs in their capacities whether they are efficacious to do the task at hand or they doubt their own abilities or distrust themselves being inefficacious to accomplish the task. Scientifically many scientists try to define self-efficacy in a satisfying way that explains the notion of selfefficacy and gives it its real significance and appreciation (Astrid,2002: 1). Bandura the founder of this term defines it as "people's beliefs about their capabilities to produce designated levels of performance that exercise influence over events that 
affect their lives" (1977:106). Self-efficacy is viewed as the people's faith that they can own the dominance over their very own work in a specific circumstance. It is also seen as a standard to which students believes that he or she has the ability to adapt to the language challenge (Rahimi\&Abedini (2009:16).

A different definition of self-efficacy states that it is a generative mechanism through which persons integrate and apply their existing cognitive, behavioural, and social skills to the performance of a given specific task( Shell et al (1989:91). It is also believed that selfefficacy is a productive system by which humans incorporate and stratify their current conception, conduct, and social dexterities to the execution of a given explicit assignment. However,self-efficacy is a significant variable for learners to dominate since it centers concentration around their confidence about the adequacy of their learning techniques (Zimmerman (1995:27).

Self-efficacy can be seen as a vital variable the learners need to control and monitor since this decisive variable sheds light on their inner idea of their ability which can decide whether they are capable or not. It is also represent a technique in people can merge and employ their own cognitive, behavioural and social skills to perform the task at hand.

\section{SELF-EFFICACY THEORY}

Self-efficacy theory is established on the actuality that humans trust in their capacities can keep up all procedures of mental and social change work through the alteration of the person's feeling of humans' dominance or self-efficacy.The theory of self-efficacy is interested fundamentally with the functionality of individual perceptive factors in the triadic mutuality model of social subjective theory with both the impact of perception on influence and conduct and the impact of conduct, influence, and environmental occasions on comprehension (Maddux (1995:7).

Maddux (1995:4) also believes that the inception and consistency of conducts and the direction of events which are the basis of self-efficacy theory are defined essentially by decisions and anticipations regarding behavioural dexterities, abilities and the probability of having the capacity to effectively adapt to natural requirements and difficulties. Self-efficacy theory preserves that these components assumes a significant role in psychic modification and dysfunction and in an efficient remedial interferences for emotional and social issues.

People's beliefs represent the central base and the real dimension of the self-efficacy theory. Bandura (1989: 1176) for instance sees that people's The amount effort that humans will spend on in an attempt to discover how will they persist in the face and time of challenges defines their actual level of motivation, while Zimmerman (2000:82-90) points out that selfefficacy tents are not a solitary alteration but instead are multidimensional in structure and its alteration is based on the scope of functioning.

Bandura (1999:2) indicates that humans' degree of motivation, emotional states, and activities are dependent more on what they ratify than on what is the situation. Henceforth, the primary concentration of realization is based on humans trust in their incidental capacities. The development of longer lasting selfguided learners is built on self-efficacy beliefs .Students' ambitions, their standard of awareness in mental proceeding, and academic accomplishments are all based on their beliefs in their own capabilities to command their academic action.

Furthermore, Bandura (1997:3) mentions that peoples' beliefs can have variety of impacts as follows:

- Such beliefs impact the directions of activities individuals choose to go after.

- The amount of diligence they put on given attempts.

- How much time they will continue when facing challenges and disappointments.

- Their flexibility and variety, regardless of whether their idea styles are self-supporting or self-hindering.

- The amount of pressure and gloom they test in adapting to exhausting environmental requirements.

- The standard of achievements they understand. 


\section{THE RELATIONSHIP BETWEEN SELF- EFFICACY AND SECOND LANGUAGE LEARNING}

Research results from a few territories demonstrate that self-efficacy is a key factor that influences students' advantage, determination, degree of exertion understudies put resources into learning, the objectives they seek after and their utilization of selfcontrolled methodologies in playing out an errand (Carmichael and Taylor, 2005; Lane, et al. 2004; Linnenbrink and Pintrich, 2003; Pajares, 1996, 2003; Schunk, 2003).

In foreign language learning settings, research studies have analyzed self-efficacy in connection to a set number of factors in particular learning systems, execution, causal attributions,and language anxiety. Still relatively few research studies have been coordinated towards the advancement of self-efficacy in these unique situations. In addition, a large portion of the examinations have researched the correlational connection between students' self-efficacy convictions and these factors, and just a couple of studies have concentrated on the easygoing connection between selfefficacy and referenced factors. Research demonstrates that self-viability in the second language setting impacts students' inspiration and learning(Burrows, 2009:10).

Self-efficacy, as a central element of human agency, mediates between learners' aptitude, past achievements and subsequent performances (Bandura, 2006). Among the different findings, the most consistent one is that learners' self-efficacy for foreign language affects performance in different language domains (Abedini\&Rahimi 2009; Hsieh, 2008; Hsieh and Kang 2010; Mills et al.2007, 2006; Tilfarlioğlu\&Cınkara, 2011; Wang et al. 2009). Taking into account the critical role of beliefs and thoughts, it is necessary to carry out much research on learners' self-efficacy and how to elevate it in educational settings such as schools and universities.

Self-efficacy, as a focal component of human office, intercedes between students' inclination, past accomplishments and ensuing exhibitions (Bandura, 2006). Among the various discoveries, the most steady one is that students' self-adequacy for unknown dialect influences execution in various language spaces (Abedini and Rahimi 2009; Hsieh, 2008; Hsieh and Kang 2010; Mills et al. 2007, 2006; Tilfarlioğlu and Cinkara, 2011; Wang et al. 2009). Considering the basic job of convictions and contemplations, it is important to do much look into on students' selfadequacy and how to lift it in instructive settings, for example, schools and colleges.

\section{3-2-1 STRATEGY}

Zygouris-Coe et al. (2004:178) suggest that efficient teachers should plan and equip their students with chances and various options to communicate inside the classroom.3-2-1 represent an adjustment from an activity that was improved by Paul nation known as the 4-3-2 fluency activity. The original activity starts with lining up students whether sitting and standing in which they face each other. Then, they need to get ready to talk on a subject they already know.

It is also believed that teachers need to involve students when the time comes to teach speaking utilizing what is called the 3-2-1 strategy in which teachers initiate the activity by promoting the students to sum up the important points of the topic, then contributing the most important ideas with their classmates, this stage is followed by sharing any sides of the topic they find interesting. The final stage is based on questioning that grants students with a chance to ask any question they still have about the topic (Zygouris-Coe et al ,2004:177).

\section{Classroom application of 3-2-1 strategy}

3-2-1 strategy is an amendment of 4-3-2 strategy. When using it in the classroom students are asked to choose a topic they are familiar with, then they talk about it for three or two minutes that relies on their level of fluency, after that they got two minutes then one. However, students need to register what they intend to say on papers. Thereafter, teacherwill ask students to mention what they have written orally. The teacher then modifies any question that students who listen may ask to the speaker if they need any help in structuring questions. The modification that teacher make on students properties to become better listeners is also really beneficial like the continuity of eye contact and 
stopping students from chatting with each other. (Frelazzo and Sypnieski, 2012)

The 3-2-1 strategy works as follows for any text or book. Teachers first ask students to discuss three things they discovered after reading the text, then to discuss two interesting things they want to note as a result of reading the text, then to ask one question they still have after reading the text. When discussing three things the students discovered, the teacher must first teach them summary skills, which he or she can do by getting them to summarize small sections of the text to make sure all are participating(Zygouris-COE et al., 2005:383)

A summary, of course, is a short, to-the-point outline of the main ideas in the text. When the students discuss two interesting things about the text they noted, teachers can encourage them to think about what they enjoyed most or what was most relevant to their everyday lives. The final step of the 3-2-1 strategy is to get students to write one question they still have about the text. This question can link the text to their everyday lives. Teachers must model this strategy to their students slowly and carefully before asking them to do it, because they must also teach their students how to summarize, thus, although this 3-2-1 strategy is useful, teachers should note that it may take some time before their students are comfortable using it, and they may have to model it several times. Obviously, teachers can use this strategy only after their students know how to summarize.

\section{METHODOLOGY}

\section{Experimental Design}

In this study, the quasi-experimental approach of research is utilized. This type of research design is considered as the only way to approximate cause and effect and also a method to control all variables. This type of research design encompasses a random treatment. For the purpose of making sure that both groups are similar, researchers predominantly manage a pretest to both groups. The reason behind applying a pretest is to gauge whether both the control and experimental groups are initiating the experiment equally.Fundametally, it represents an examination of whether there are preexisting variations between both groups in capabilities or other properties (Lodico et al, 2006:185).Accordingly, to obtain the aims set for this study, two groups are randomly chosen as experimental and control groups. Both groups are pre-tested. Then the experimental group is to be taught with the experimented strategy, while the control group is taught with conventional technique as prescribed in the teachers' book .Table (1) illustrates the experimental design adapted.

Table (1): The experimental design

\begin{tabular}{|c|c|c|c|}
\hline Experimental Group & $\begin{array}{ll}- & \text { Speaking Pretest } \\
- & \text { Self-efficacy } \\
& \text { Pretest }\end{array}$ & $\begin{array}{l}\text { Independent Variable } \\
\text { (3-2-1 strategy) }\end{array}$ & $\begin{array}{ll}- & \text { Speaking } \\
& \text { Posttest } \\
& \\
- & \text { Self-efficacy } \\
& \text { Posttest }\end{array}$ \\
\hline Control Group & $\begin{array}{ll}- & \text { Speaking Pretest } \\
- & \text { Self-efficacy } \\
& \text { Pretest }\end{array}$ & 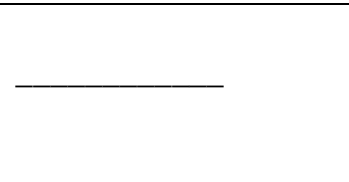 & $\begin{array}{ll}- & \text { Speaking } \\
& \text { Posttest } \\
- & \text { Self-efficacy } \\
& \text { Posttest }\end{array}$ \\
\hline
\end{tabular}

\section{Sample of the study}

The population of the present study covers the $5^{\text {th }}$ stage preparatory school students at Baghdad Governorate.Al-Ferdos secondary school for girls is randomly selected. In this school the number of the $5^{\text {th }}$ stage student is 276 which are divided into five sections, and two of the five sections are randomly chosen. They are section D which includes 51 students to be theexperimental group and section B which includes 53 to be the control group. After eliminating the repeaters in every section, the total number of the 
sample is 64 students, 32 students in the experimental group and 32 students in control group.

The experimental group is taught speaking according to the 3-2-1 strategy, while the control group is taught speaking according to the traditional technique that are proposed in the teacher's guide .

\section{Instruments of the study}

Brown (2001:6) points out that a test may take the form of a series of questions or statements to which respondents can react by selecting from among existing answers. A scale can be defined as a measurement instrument consisting of attitude or belief items that reflect an underlying structure toward some attitude or belief object (Stacks 2010:27).For the purpose of attaining the goal set for this study and most importantly to verify the hypotheses, a speaking performance posttest and a speaking self-efficacy scale are employed :

\section{Speaking performance posttest}

The speaking performance test takes the form of individual interview with each student in both experimental and control groups. Eight different topics for the interviews are decided by students themselves. Eight questions are prepared to be asked in each topic.

\section{Speaking self-efficacy scale}

A speaking self-efficacy scale is adopted from HadjerSeraoui (2016). The speaking self-efficacy scale encompasses 28 items. Each item has four responses that are measured on a four points' Likert scale. The scores that are given to each response range from strongly agree to strongly disagree.

\section{Application of the experiment}

Lesson plans for the experimental group(according to 3-2-1 strategy) and control group (according to the teaching procedures prescribed in the teacher's book) are prepared by the researchers for the experiment.

After checking and securing the validity and reliability of the data collection instruments of the study, the experiment is initiated on the $8^{\text {th }}$ of Oct .2018 and lasted for twelve weeks during the academic year 2018-2019 to end up on the $6^{\text {th }}$ of Jan 2019. The same number of daily lessons are given to both groups during this period.

\section{FINAL RESULTS}

\section{Results related to the first aim}

As shown in table (2), the mean scores of the experimental and control groups in the speaking performance posttest are 90.031 and 64.125 with standard deviations 30.692 and 22.588 respectively. The computed t-test value is found to be 3.846 which is higher than the critical value 2.000.

Table (2): t-value of students' scores in the speaking performance posttest

\begin{tabular}{|l|l|l|l|l|l|l|l|}
\hline Group & Number & \multirow{2}{*}{ Mean } & SD & \multicolumn{2}{|l|}{ t-value } & DF & Results \\
\cline { 3 - 7 } & & & Computed & Critical & & \\
\hline Experimental & 32 & 90.031 & 30.692 & 3.846 & 2.000 & 0.05 & $\begin{array}{l}\text { Significant } \\
\text { For the } \\
\text { Experimental } \\
\text { group }\end{array}$ \\
\hline Control & 32 & 64.125 & 22.588 & & & & \\
\hline
\end{tabular}


And to verify the size of effect of the independent variable (3-2-1 strategy), Kouhan formula is used for this purpose which indicates that the effect size is weak if it is less than $(0.41)$, medium if it is ranging between (0.70- 0.41$)$, and high if the size of effect is more than (0.70). The result shows that the size of effect of the independent variable in this study reaches (1.146) which indicates that the size of effect is large (Table3). According to the results achieved, the first null hypothesis in this study is rejected.

Table (3): The effect size

\begin{tabular}{|l|l|l|l|}
\hline $\begin{array}{l}\text { Mean of the experimental } \\
\text { group grades }\end{array}$ & Mean of the control group grades & SD & Size of effect \\
\hline 90.031 & 64.125 & 22.588 & 1.146 \\
\hline
\end{tabular}

\section{Results related to the second aim}

The mean scores of the experimental and control group in the speaking self-efficacy scales are found 89.281 and 80.218 with standard deviations 10.399 and 12.551 respectively. The t-test computed value 3.145 is higher than the critical one 2.000 .Table (4) illustrates the t-value in the speaking self-efficacy scale.

Table (4):t-value of students' scores in the speaking self-efficacy posttest

\begin{tabular}{|c|c|c|c|c|c|c|}
\hline \multirow{2}{*}{ Group } & \multirow{2}{*}{ Number } & \multirow{2}{*}{ Mean } & \multirow{2}{*}{ SD } & \multicolumn{2}{|l|}{ t-value } & \\
\hline & & & & critical & computed & \\
\hline Experimental & 32 & 89.281 & 10.399 & \multirow{2}{*}{2.000} & \multirow{2}{*}{3.145} & \multirow{2}{*}{$\begin{array}{l}\text { Significant } \\
\text { For the } \\
\text { Experimental } \\
\text { group }\end{array}$} \\
\hline Control & 32 & 80.812 & 12.551 & & & \\
\hline
\end{tabular}

The results indicate the supremacy of the experimental group over the control group. And to verify the size of the independent variable (3-2-1 strategy) effect, the Kouhan formula, using this formula is also used which reveals that the size of effect of the independent variable in this study reaches (0.717) which indicates also a large size of effect (See table 5). Accordingly the second hypothesis in this study is also rejected.

Table (5): The effect size

\begin{tabular}{|l|l|l|l|}
\hline $\begin{array}{l}\text { Mean of the experimental } \\
\text { group grades }\end{array}$ & Mean of the control group grades & SD & Size of effect \\
\hline 89.218 & 80.218 & 12.551 & 0.717 \\
\hline
\end{tabular}




\section{DISCUSSION OF RESULTS}

This experiment is designed to determine if students would make a progress in their speaking skill and positively alter their feelings towards their inner perceptions concerning learning speaking. Data collected by the adopted instruments for this study reveals the substantial improvement in students' speaking performance during oral posttest. The experimental group also shows obvious positive modification in students believes and inner perceptions of their self-efficacy concerning learning the speaking skill.

Based on the findings of this study, the results show the success of the 3-2-1 strategy in promoting students' speaking self-efficacy and speaking performance. The statistical analysis of the data demonstrates the prosperity of the suggested strategy which is embraced by the researchers and confirmed to be efficient in upgrading the speaking.

The suggested strategy has empirically proved to be a prosperous mannerism to upgrade students speaking performance and to positively raise their believes and perceptions of their self-efficacy to learning speaking, this can be imputed to the following reasons:

1- 3-2-1 strategy motivates students to express themselves and communicate not only with the teacher but also with their classmates.

2-This strategy creates a positive impact which comes from creating positive atmosphere inside the classroom that prepares students emotionally and mentally to use the language to speak. This kind of positive atmosphere leverages the students' performance specifically in speaking and raises their evaluation of their beliefs and perceptions of their self-efficacy concerning speaking.

3- The strategyactivities have the ability to maximize students' occasions to speak during the lesson and provide the possibleadvantage of student-student interaction. Eliciting information and opinions from the teacher and the students creates the necessity for students to interact. So they should spend all the time specified for the speaking skill to interact.

\section{CONCLUSIONS}

As a result of the empirical evidence that has been detected in this study, besides the researchers' own observations during the experiment. The following deductions are inferred:

- The strategy of 3-2-1 is effective in improving Iraqi EFL preparatory school students' speaking performance.

-The strategy of 3-2-1 can be effectively used to promote Iraqi EFL preparatory school students' speaking self-efficacy.

-Utilizing the 3-2-1 strategy increases students interaction inside the classroom, since it frees them frompressure through creating a positive atmosphere that activate, excite, and encourage them all to participate. This leads them to kill their hesitation and fear from speaking and give them better chances to practice, comprehend, and develop their performance through the actual use of the language.

-This strategy fosters students' level of evaluation and appreciation concerning to what extent they believe in their own ability to learn to speak which in turn raise their speaking self-efficacy.

\section{RECOMMENDATIONS}

Based on the results that are presented in this study, the following recommendations are submitted:

1-EFL teachers should be aware of the effectiveness of 3-2-1strategy and able to employ it in their classrooms to promote their students' speaking skill.

2-EFL teachers should be aware of the affective factors that may hinder the development of their students' speaking performance such as self-efficacy, anxiety, motivation, etc. EFL teachers should be also aware of how to reduce the negative effects of such factors by employing effective teaching strategies like the one experimented in this study.

3-It is recommended that classroom teachers give students the time that they need to finish their speaking tasks as when they feel anxious or afraid this may lead to the failure of completing the assignment in due time. 
4-Student past negative attempts to participate in a speaking activity weakens their confidence and most importantly their faith in their self-efficacy beliefs. That is why teachers are recommended to create a comfortable atmosphere inside classroom far from, punishment, complexities, anxiety, stress and threatening, which in return can help in creating a safe environment for students.

5-Teachers need to build healthy relationships with their students which are based on mutual respect to help students speak out their problems and this lead to aiding students in expressing themselves more openly and freely. Such relationships can lead to build more confident learners.

\section{REFERENCES}

Al-Salihi,H.D.(2006)The Effect of Dramatization in Teaching Situational Dialogues on the Achievement of EFL College Students.M.A Thesis. University of Mustansiriyah, College of Education.

Al-Shimmaary,S.H.Q(2003)The Effect of Using Task-Based Approach in Teaching Conversation on EFL College students' Oral Performance.M.A Thesis. University of Baghdad College of Education for Woman.

Baker, J. \&Westrup, H. (2003). Essential Speaking Skills: A Handbook for language Teachers. London: Continuum, Inc.

Bandura, A. (1989). Self-regulation of motivation and action through internal standards and goal systems. In A. Pervin (Ed.), Goal concepts in personality and social psychology (pp. 19-85). Hillsdale, NJ: Lawrence Erlbaum Associates.

Bandura, A. (1997).Self-efficacy: The exercise of control. New York: W.H.Freeman and Company.
Bandura, A. (1999). Social cognitive theory: An agentic perspective. Asian Journal of Social Psychology, 2(1), 21-41.

Bandura, A. (2006). Guide for constructing selfefficacy scales. In F. Pajares\& T. Urdan (Eds.), Self-efficacy beliefs of adolescents (pp. 307-337). Greenwich, CT: Information Age Publishing.

Brown, K. J. (2001).Changing Assessment Practicing Science and Mathematics. New York: Cambridge University Press.

Burns \&ChuenMeng.(2012) "Teaching Speaking :A holistic Approach": Cambridge University Press.

Burns, A. \& Joyce, H. (1997). Focus on speaking. Sydney: National Center for English Language Teaching and Research.

Burrows, L. (2009). Assessing Self-Efficacy: Constructing a Scale. Kinki University English Journal, 4, p. 1-12.

Carmichael, C., \& Taylor, J. A. (2005). Analysis of student beliefs in a tertiary preparatory mathematics course. International Journal of Mathematical Education in Science and Technology,36(7), 713-719

Celce-Murcia, M. (ed). (2001). Teaching English as a Second or Foreign Language, 3rd edition. Boston, M. ed: Heinle\&Heinle.

Cushman, D. \& Cahn, D. (1985). Communication in Interpersonal Relationships. New York: SUNY Press

Feist, J. \& Feist, G.J. (2002).Theories of personality (Fifth Edition).Boston: McGraw Hill. Florez, M. A. (1999). "Improving Adult English 
(IJRSSH) 2020, Vol. No. 10, Issue No. II, Apr-Jun

Language Learners' Speaking Skills". ERIC Digest. (ERIC Document Reproduction Service No. ED: 435204)

Freelazzo, L. \&Sypnieski, K. H. (2012) The ESL/ELL Teacher's Survival Guide. John Wiley \&Sonss,Inc.

Hsieh, P. H. Kang, H. S. (2010). Attribution and self-efficacy and their interrelationship in the Korean EFL context. Language Learning, 60(3), 606-627.

Hsieh, P.-H. (2008). - Why are college foreign language students' self-efficacy, attitude, and motivation so different?॥ International Education, 38(1), 76-94.

Lane, J., Lane, A., \&Kyprianou, A. (2004). Selfefficacy, self-esteem and their impact on academic performance. Social Behaviour and Personality, 32, 247-256.

Linnenbrink, E. A., \&Pintrich, P. R. (2003). The role of self-efficacy beliefs in student engagement and learning in the classroom. Reading \& Writing Quarterly, 19, 119.

Lodico,M.G,Spaulding,D.T\&Voegtle,K.H .(2006)Methods in Educational Reasrerch.John Wiley and Sons Inc.

MacCarthy, P. (1972). Talking of Speaking. London: Oxford University Press.

Maddux, J. (1995) Self-Efficacy, Adaptation, and Adjustment Theory, Research, and Application. Springer Science Business Media New York.

Mills, N., Pajares, F., \& Herron, C. (2006). A reevaluation of the role of anxiety: Selfefficacy, anxiety and their relation to reading and listening
e-ISSN: 2249-4642, p-ISSN: 2454-4671

proficiency. Foreign Language Annals, 39(2), 276-295.

Mills, N., Pajares, F., \& Herron, C. (2007). Selfefficacy of college intermediate French students: Relation to achievement and motivation. Language Learning, 57(3), 417442 .

Nunan, D. (1991). Language Teaching Methodology: Book for Teachers. New York: Prentice Hall International.

Pajares, F. (1996). Self-efficacy beliefs in academic settings [Electronic version]. Review of Educational Research, $66,543-578$.

Pajares, F. (2003). Self-efficacy beliefs, motivation and achievement in writing. Reading and Writing Quarterly, 19(2), 139-158. http://dx.doi.org/10.1080/10573560 390143085

Rahimi,A.,\&Abedini,A.(2009)The Interface between EFL Learners' SelfEfficacy concerning Listening Comprehension and Listening Proficiency.Novitas Royal, Vol:3(1),14-28.

Richards,(2008).Teaching Listening and Speaking. From Theory to Practice. Cambridge University Press.

Schunk, D. (1981) Modeling and attributional effects on children's achievement: A self-efficacy analysis. Journal of Educational Psychology, 73, 93105.

Schunk, D. H. (2003). Self-efficacy for reading and writing: Influence of modeling, goal setting and self-evaluation. Reading and Writing Quarterly: Overcoming Learning Difficulties, 19(2), 159-172. 
Shell, et al. (1989).Self-efficacy and outcome expectancy mechanisms in reading and writing achievement. Journal of Educational Psychology.81:91100 .

Tilfarlioğlu, F. T., \&Ciftci, F. S. (2011). Supporting Self-efficacy and Learner Autonomy in Relation to Academic Success in EFL Classrooms (A Case Study). Theory and Practice in Language Studies, 1(10), 12841294.

http://dx.doi.org/10.4304/tpls.1.10. 1284-1294

Wang, J., Spencer, K., \& Xing, M. (2009). Metacognitive beliefs and strategies in learning Chinese as a foreign language. System, 37, 4656.

Widdowson, H. G. (1990). Aspects of Language Teaching. Oxford: O. U.P.

Zimmerman, B. J. (2000). Attaining selfregulation: A social cognitive perspective. In M. Boekaerts, P. R. Pintrich, \& M. Zeidner (Eds.), Handbook of Self-regulation (pp. 13-39). San Diego: Academic Press.

Zimmerman, B.J (1995). Self-efficacy and educational development. In Bandura, A. (Ed.), Self-efficacy in changing society (pp. 202-231). Cambridge: Cambridge University Press.

Zygouris-COE, V., Wiggins, M., \& Smith, L. (2005). Engaging students with the text: the 3-2-1 strategy. The Reading Teacher. 58 ( 4 ), 381-384. 